Proceedings of the EUROPROBE meeting on the TRANS-EUROPEAN SUTURE ZONE, held at Liblice, Czech Republic, October 17-22, 1993, for publication by the Czech Academy of Sciences.

\title{
THE CONCEALED CALEDONIDE BASEMENT OF EASTERN ENGLAND AND THE SOUTHERN NORTH SEA - A REVIEW
}

${ }^{1}$ Tim Pharaoh, ${ }^{2}$ Richard England and ${ }^{1}$ Mick Lee

1. British Geological Survey, Keyworth, Notts., NG12 5GG, UK.

2. B.I.R.P.S., Bullard Research Laboratories, Cambridge, UK.

\begin{abstract}
The Precambrian and early Palaeozoic ('Caledonian') metamorphic basement of E England and the southern North Sea comprises a number of distinct structural elements. The Midlands Microcraton was a persistent structural element throughout the early Palaeozoic. It lay in the back-arc region of subduction-related magmatic arc systems in Ordovician time, and was probably emergent. In Silurian time, it formed a fault-bounded platform distinct from deep water basins in Wales, N England and E Anglia. Acadian deformation and metamorphism was rather weak. The Concealed Caledonides of E England have a NW-SE structural grain and were more intensely deformed and metamorphosed by the Acadian orogenic phase. Deep seismic reflection surveys in the offshore part of this belt indicate the presence of inclined zones of reflectivity in the mid-crust, interpreted as thrusts. The age of these structures is uncertain. They could have formed during the collision of the Avalonia Microplate with Baltica in late Ordovician time, or could be entirely Acadian structures.

The Dowsing-South Hewett Fault Zone (DSHFZ) is a long-lived crustal lineament, reactivated throughout late Palaeozoic and Mesozoic time. A dipping reflector at the Moho and in the upper mantle, has been mapped parallel to, and just coastward of, the fault zone, and may mark the trace of an Ordovician subduction zone and/or crustal suture. Between the DSHFZ and the Trans-European Fault Zone, crystalline basement lies deeply buried beneath the Anglo-Dutch Basin. The nature and history of this crust is poorly constrained by geological evidence. It may belong to a terrane suspect with respect to Avalonia. On the Mid North Sea High itself, several boreholes prove sedimentary rocks which experienced greenschist and possibly amphibolite facies metamorphism in late Ordovician time. This crust was apparently caught up in the collision zone between Avalonia and Baltica. Late Ordovician deformation, associated with this collision event, is recognised elsewhere in Avalonia, but is less penetrative in nature.
\end{abstract}

\section{Introduction}

In the area reviewed, 'Caledonian' metamorphic basement is largely concealed by a cover of late Palaeozoic, Mesozoic and Cenozoic strata. In the Midlands of England, the younger cover is relatively thin and outcrops in Leicestershire and Warwickshire provide insights to the history of the Midlands Microcraton. Mesozoic strata thicken across the Eastern England Shelf, towards the North Sea. The 'Caledonide' deformation belt inferred to underlie the shelf is known only from deep boreholes. The latter provide useful information on the lithology, age and metamorphic grade of rocks within the belt (Pharaoh et al. 1987, Molyneux 1991, Woodcock 1991). The structural history and geometry of this deformation belt has been inferred from analysis of geophysical potential field data (Lee et al. 1991). Deep seismic reflection data demonstrating the internal structure of the deformation belt are restricted to 
the offshore part of the Eastern England Shelf (Blundell et al. 1991, Klemperer \& Hobbs 1992). By contrast, the nature and history of the crystalline basement underlying the North Sea south of the Trans-European Fault Zone is very poorly known. The scant lithogical and isotopic information, derived from boreholes on the mid-North Sea High drilled during the early phase of hydrocarbon exploration, has been summarised by Frost et al. (1991). This paper attempts to review the evolution of the metamorphic basement of eastern England and the southern North Sea in the context of the development of the Trans-European Fault Zone during early Palaeozoic time.

The term 'Eastern Avalonia' has been applied to the eastern part of the Avalonia Microplate (Soper et al. 1987) i.e. the Caledonides of S Ireland, S Britain and Belgium. Palaeomagnetic evidence for separation of this area from New England and Maritime Canada (i.e. 'Western Avalonia') in early Palaeozoic time is presently lacking (McKerrow, 1993, pers. comm.). Thus in the text, the microplate will be described for brevity as 'Avalonia' although the reader should be aware we refer to the eastern part of it throughout.

\section{Midlands Microcraton}

This wedge-shaped region, referred to by Wills (1978) as the 'English Microcraton', and numerous other authors (e.g. Cope et al. 1992) as the 'Midland Platform', occupies the English Midlands region (Fig. 1). The southern boundary of the region is the Variscan Front (Fig. 1), the northern limit of Variscan foreland fold-thrust belt deformation. Seismic reflection data (Chadwick et al. 1983) demonstrate the continuation of the Precambrian basement of the Variscan foreland beneath the overthrust belt for some considerable distance. On the NW edge of the microcraton lies the Welsh Basin, comprising a tripartite stack of basinal sequences ranging in age from Cambrian to early Devonian (Woodcock 1990). The boundary is marked by a complex zone of SW-NE trending faults (Fig. 1) known as the Welsh Borderland Fault System (Woodcock \& Gibbons 1987), reactivated periodically throughout the early Palaeozoic. Precambrian basement (Uriconian volcanic group) is incorporated in transpressional duplex structures (Woodcock \& Fischer 1986) within this zone. The intensity of deformation and metamorphism increases into the basin, away from this tectonic boundary. The $\mathrm{N}$ and NE boundary of the microcraton is poorly known at present, and in any case is transitional in nature (Woodcock 1991). In Fig. 1, the NE limit of the microcraton is taken at the Thringstone Fault, $\mathrm{W}$ of the Charnwood (Precambrian) inlier, which is inferred to occupy a fault duplex comparable in style to the Uriconian inliers lying within the Welsh Borderland Fault System. To the SE, the boundary is defined using the evidence of the Silurian shelf to basinal facies transition (Molyneux 1991).

The Precambrian crust of the Midlands Microcraton consists of a heterogeneous complex of volcanic arc and marginal-basin complexes accreted in Neoproterozoic time (Thorpe et al. 1984), from about 680 to $560 \mathrm{Ma}$ (Tucker \& Pharaoh 1991). The apparent absence of much older Proterozoic crust within this Avalonian accretionary complex suggests its development in a distal position with respect to the Gondwana margin, outboard of the Cadomian terranes. At least 2 Precambrian terranes are present within the microcraton, sutured along the N-S Malvern lineament (Pharaoh et al. 1987b), which has been reactivated throughout Phanerozoic time. It is thus inferred that all of the Precambrian inliers (Shropshire, Malverns, Charnwood and Nuneaton) are 'pop-up' structures associated with wrench-faults of probable Caledonian age, reactivated in the Variscan Orogeny.

Across most of the area of the microcraton the Precambrian basement is overlain by a rather uniform Cambrian clastic sequence deposited in water of increasing depth with time, 
reflecting subsidence of the rifted margin of the Avalonia Microplate as it drifted away from Gondwana during Cambrian time. Changes in the geometry of the rift-basins in Tremadoc time (Smith \& Rushton 1993) presaged the onset of subduction volcanism in the Welsh Basin (Kokelaar et al. 1984) and reflected the onset of (lapetus) ocean closure. Strata of Ordovician age younger than Tremadocian are absent, although numerous minor intrusions of calcalkaline lamprophyric affinity (Thorpe et al. 1993) were emplaced into a tectonically active (Carney et al. 1992) emergent back-arc region prior to the deposition of Silurian strata. The latter comprise shallow-water carbonate and clastic sedimentary rocks of Llandovery to Pridoli age, deposited across the Midlands Platform, the Silurian manifestation of the microcraton. The metamorphic grade of the Cambrian-Tremadoc cover is typically diagenetic to low anchizone (Merriman et al. 1993). Deformation of the sedimentary cover of the microcraton during the Acadian phase of deformation in Emsian time (Soper et al. 1987) was minimal, and restricted to the development of spaced cleavage towards the margins of the microcraton. An earlier, 'Shelveian' phase of deformation in late Ordovician (Ashgill) time is associated with dextral strike-slip on the Pontesford-Linley fault system (Lynas 1988, Woodcock \& Gibbons 1988), uplift of the adjacent Towi Anticline and folding in pre-Ashgill strata (Toghill, 1992). Folding of Cambro-Ordovician strata in Warwickshire, penecontemporaneous with emplacement of the lamprophyric Midlands Minor Intrusion Suite (Carney et al. 1992) may also have occurred at this time.

\section{Concealed Caledonides of Eastern England}

Boreholes in eastern England from the eastern Pennines to the Thames Estuary demonstrate that the sub-Carboniferous basement is composed of low grade metasedimentary rocks of Ordovician and Silurian age (Turner 1949, Molyneux 1991), and plutonic and volcanic igneous rocks (Pharaoh et al. 1991, 1993a). Fossiliferous sedimentary rocks of basinal facies, with steep dips and well developed cleavage were encountered by boreholes in the last century (Bullard et al. 1940). Plutonic rocks of high-K calc-alkaline affinity were recognised by Le Bas (1972, 1982).

Biostratigraphic evidence for faunal provinciality, requiring the presence of a Tornquist Sea (ocean) separating Avalonia and Baltica during Ordovician time (Cocks \& Fortey 1982), gave a new stimulus to studies of the eastern England basement. The first results of a thorough review of the available borehole evidence, including mica-crystallinity data, geochemical and isotopic data and available structural information (Pharaoh et al. 1987a), supported the concept of a NW-SE trending fold belt linking with the Caledonides of central Europe proposed by Turner (1949).

The metamorphic data indicated that Silurian metapelitic rocks

in East Anglia had attained epizone grade (= greenschist facies) as a result of Acadian metamorphism. A rise in metamorphic grade was observed from the microcraton into the fold belt. Geochemical data demonstrated the dissimilarity of concealed volcanic rocks to the Charnian (Precambrian) volcanic rocks, and greater similarity to Caledonian plutonic rocks at Mountsorrel and in S Leicestershire. Various volcanic provings yielded Ordovician or early Devonian Rb-Sr isotopic ages (Pharaoh et al. 1987a, 1991). The tectonic model for the concealed Caledonides at this time placed considerable emphasis upon analogues in the adjacent Caledonide basins in Wales and the Lake District i.e. the development of deep basins containing thick sequences of early Palaeozoic sedimentary strata, with interstratified volcanogenic sequences of Ordovician age.

The results of further studies were published in the proceedings of the Anglo-Brabant Massif 
conferences held in Brussels in 1989 (Vanguestaine et al. 1991) and Keyworth in 1992 (Pharaoh et al. 1993b). The study of metamorphic crystallinity was extended to cover virtually every early Palaeozoic proving in eastern England (Merriman et al. 1993), and confirmed the contrast in metamorphic grade between mudrocks on the microcraton (diagenetic to low anchizone) and in the concealed Caledonides (low anchizone to epizone). The presence of subduction-related calc-alkaline plutonic rocks in a NW-SE trending belt from Derby to Cambridge, representing an extension of the occurrences recognised by Le Bas $(1972,1982)$ was demonstrated (Pharaoh et al. 1993a). Noble et al. (1993) demonstrated the late Ordovician age of felsic magmatic rocks in the vicinity of The Wash using U-Pb zircon data, and presented $\mathrm{Nd}$ isotope data indicating a probable early Palaeozoic age for most other occurrences of concealed volcanic rocks. Thorpe et al. (1993) identified a subductionmagmatic component in the Ordovician lamprophyric minor intrusions of the microcraton, here inferred to occupy the back-arc region. Thus the presence of subduction-related magmas of late Ordovician age in the concealed Caledonides is well documented, as in Belgium (André \& Deutsch 1986, André 1993), in contrast to the view expressed by Berthelsen (1992) that they are absent. Pharaoh et al. (1993a) speculated that this arc-related magmatism was generated in response to the subduction of oceanic lithosphere from the Tornquist Sea beneath the Avalonia Microplate over a period of about $50 \mathrm{Ma}$. They also speculated that the oceanic trench forming the leading edge of the Avalonia Microplate lay in the southern North Sea region, adjacent to the Dowsing-South Hewett Fault Zone (see later section).

One of the most significant problems in interpreting the history and composition of the concealed Caledonides is the poor precision of biostratigraphic dating of boreholes, particularly in comparison to Belgium (e.g. c.f. Verniers \& Van Grootel 1991, De Vos 1993, Servais et al. 1993). Thus while it is possible to recognise a distinctive basin of broadly Silurian to earliest Devonian age in East Anglia (Molyneux 1991, Woodcock \& Pharaoh 1993), the biostratigraphic data are of insufficient precision to indicate whether a transition from anoxic basin slope to shallower water environments occurred in time or over space. The presence of other late 'successor' basins comparable to the Anglian Basin cannot be ruled out. Furthermore, large areas of the basement in the area between the Pennines and The Wash, are composed of metasedimentary rocks which have so far failed to yield biostratigraphic evidence, and may even be of Precambrian age (Lee et al. 1991, Merriman et al. 1993). It is hoped to address these biostratigraphical problems in the near future.

The structural geometry of the concealed Caledonides is not directly observable. Studies of geophysical potential field images (e.g. Lee et al. 1990, 1991, 1993) have demonstrated that the concealed basement of eastern England is characterised by a number of SE and SSE-trending magnetic and gravity lineaments. The cause of the broad magnetic anomaly ridge extending from northern England to East Anglia (the Furness-Norfolk Magnetic Anomaly, Fig. 1) has been the subject of much speculation (Bott 1967, Wills 1978, Allsop 1987, Cornwell \& Walker 1989, Lee et al. 1990, 1991). Wills (1978) referred to this feature as the Furness-Ingleborough-Norfolk Magnetic Ridge and believed it was due to the presence of magnetic metamorphic rocks, probably Precambrian, at relatively shallow depth. The IGS borehole at Beckermonds Scar (Berridge, 1982) subsequently demonstrated the presence of magnetite-bearing Ordovician metasedimentary rocks. Busby et al. (1993) have modelled the magnetic anomaly as due to the presence of a substantial (up to $50 \mathrm{~km}$ wide) body of magnetic metasedimentary or igneous rock. The magnetic anomaly belt is associated with a number of gravity lows. The presence of granite was demonstrated by drilling in Wensleydale (Bott 1967, Dunham 1974), but postulated granites at Market 
Weighton (Bott 1975) and in the vicinity of The Wash (Chroston et al. 1987) have not yet been proven. The emplacement of the microgranite proven by Claxby Borehole (Fig. 1) to NW of The Wash (Pharaoh et al. in prep) has been dated at $457 \pm 20 \mathrm{Ma}$ by the U-Pb zircon method (Noble et al. 1993), and suggests that at least some of these inferred granites may have been emplaced contemporaneous with Ordovician arc magmatism (Pharaoh et al. 1993), as in the Lake District (Cooper et al. 1993). While magnetic metasediments may make a contribution to the magnetic anomaly, we argue here that the primary component of the anomaly is due to the presence of Ordovician subduction-related magmatic rocks. If this hypothesis is correct, then the Furness-Norfolk Magnetic Anomaly may mark the trace of the magmatic arc linking the Ordovician calc-alkaline volcanic provinces of the Lake District and eastern England, whose presence was inferred by Le Bas (1975) and Pharaoh et al. (1991).

Geophysical images resolve numerous SE-trending magnetic lineaments which may reflect either Precambrian or Caledonian tectonic structures within the basement. Soper et al. (1987) have commented upon the prevalent SE-trend of Carboniferous basinal structures in eastern England, and infer that these too are inherited from reactivation of the basement structures.

The deformation of the concealed Caledonides has hitherto been considered an entirely Acadian event (Soper et al. 1987, Pharaoh et al. 1987a). However, a late Ordovician deformation phase has been documented in the Pennine inliers of northern England (Arthurton et al. 1988), giving rise to a significant unconformity at the base of the Windermere Group, and contemporaneous with the Shelveian phase of the Welsh Borders. An unconformity is suspected at the base of Powys Supergroup (Woodcock 1990) equivalents in the Anglian Basin (Lee et al. 1991, Woodcock \& Pharaoh 1993) but not yet proven by drilling. Thus the possibility of pre-Acadian deformation in eastern England cannot be ruled out, and isotopic evidence from the basement of the mid North Sea region (see next section) makes it rather likely.

Noble et al. (1993) have published isotopic evidence demonstrating an Ordovician age for some, and a probable Ordovician age for most, of the concealed volcanic and plutonic rocks of the concealed Caledonides, as described above. 2 provings of felsic welded tuff have yielded Avalonian (620-612 Ma) ages however, despite their petrographic and geochemical dissimilarity to Charnian volcanic rocks. Pharaoh et al. (1993) have inferred that these Precambrian inliers are involved in major thrust zones within the deformation belt.

Further evidence for Caledonian thrust structures in the middle crust is provided by deep seismic reflection data across the Eastern England Shelf in the southern North Sea (Blundell et al. 1991, Klemperer \& Hobbs, 1992, Cameron et al. 1992). Hydrocarbon boreholes in this region e.g. UK 47/29A-1 and 53/16-1 have encountered deep water sedimentary rocks of Ordovician and Silurian age, comparable to the occurrences in East Anglia, and the area is therefore interpreted as the offshore extension of the concealed Caledonides. Dipping reflectors interpreted as Caledonian thrusts and possible antiformal ramps occur in the crust of the Hewett Shelf (Blundell et al. 1991, Blundell 1993), and are well imaged by profiles MOBIL-6 and -7 as well as other surveys. Klemperer \& Hobbs (1992) mapped some of these reflective zones and demonstrated that they have a SE-strike, parallel to the edge of the Anglo-Dutch Basin. Near the South Hewett Fault Zone, these thrusts have an inferred NEdirected vergence. Further S, some appear to verge towards SW on the Shell 82-101 seismic profile (Klemperer \& Hurich, 1992).

The likely presence of thrust faults means that the internal structure of the concealed Caledonide deformation belt is more complex than anticipated by Pharaoh et al. (1987a). The presence of Precambrian inliers presents a major contrast with the Welsh Basin, which 
Pharaoh et al. (1987a) regarded as a possible structural and lithological analogue, the two areas lying on opposing flanks of the microcratonic 'indenter' advocated by Soper et al. (1987).

\section{Basement of the Southern North Sea}

The Dowsing-South Hewett Fault Zone (DSHFZ) represents a major crustal boundary (Fig. 1), separating crust of distinctly different seismic reflectivity (Blundell et al. 1991, Klemperer \& Hobbs 1992). The DSHFZ has exhibited a complex history of reactivation through Permian and Mesozoic time, and probably acted as a syndepositional fault in Carboniferous time (Leeder \& Hardman 1989). The crust underlying the Anglo-Dutch Basin, to north of the DSHFZ is poorly reflective in the middle crust, in contrast to the situation below the South Hewett Shelf, where numerous dipping reflective zones are recognised, as described above. The lower crust of the Anglo-Dutch Basin exhibits good reflectivity, again in contrast to the Hewett Shelf, and it is possible to recognise a well-defined relection Moho (Klemperer et al. 1986) at 11 to $11.5 \mathrm{~s}$ TWT throughout the region. Deep seismic profiles MOBIL-6, -7 and SNST83-07 image a SWdipping event (X-reflector of Blundell et al. 1991, and Fig. 2) at the Moho and in the upper mantle parallel to, and just coastward of, the DSHFZ (?England, in press), as depicted schematically in Fig. 1. Pharaoh et al. (1993) speculated that this reflector might represent a relic of the Ordovician subduction zone responsible for the generation of the calc-alkaline volcanic and magmatic suites of the Caledonides of eastern England and Belgium, recording the underflow of oceanic lithosphere from Tornquist's Sea (Cocks \& Fortey, 1982). The contrast in reflectivity patterns in the crust on either side of the zone described above also suggest that it may represent a terrane boundary, which we refer to as the Dowsing-South Hewett Suture. The continuation of the putative crustal suture marked by the X-reflector to the north-west of its mapped position on SNST83-07 is highly conjectural. It probably continues NW towards Flamborough Head, and then up the north coast of England, just landward of the BIRPS reflection profiles in this area (Fig. 1). The inversion history of the Vale of Pickering is comparable to that of the Sole Pit Trough, and might suggest continuity of the DSHFS with the Vale of Pickering Fault Zone. However, we prefer to continue the DowsingSouth Hewett Suture NW along the Yorkshire coast, via the Peak Trough, because this preserves the geometrical relationship of the suture to the Caledonian magmatic arc (FurnessNorfolk Magnetic Anomaly) inferred above.

Of the deep basement provings on the northern flank of the Anglo-Dutch Basin, only one (Netherlands A/17-1) is likely to represent a proving of the basement of the southern North Sea Terrane. The others (reviewed in the next section) appear to lie north of the lapetus Suture or the Trans-European Fault Zone (Fig. 1), and thus beyond the inferred limits of the terrane. A/17-1 proved a biotite granite showing little evidence for deformation but much low temperature alteration. It may be representative of the granitic plutons inferred by Donato and Megson (198) to underpin the southern margin of the Mid-North Sea High further west (Fig. 1). The Ar-Ar age of $346 \pm 7 \mathrm{Ma}$ is relatively young for a Caledonian granite, and is regarded by Frost et al. (1981) as a minimum age, affected by alteration.

The presently available geophysical data appear to allow 3 alternative origins for the crust underlying the Anglo-Dutch Basin in the SNS:

1). The region could represent a flake of the Avalonia Microplate which has suffered intense deformation and metamorphism as a result of the collision of Avalonia and Baltica.

2). The region might have affinities with the high grade metamorphic terranes of the Scottish and Norwegian Caledonides. 
3). A third possibility is that the basement of the Anglo-Dutch Basin is 'suspect' in the sense of Coney et al. (1980) with respect to all the surrounding terranes, and may represent an entirely exotic crustal terrane (Southern North Sea Terrane) caught up along the Avalonia/Baltica suture.

Detailed isotopic studies of basement provings such as $A / 17-1$ are required to determine which of these hypotheses is correct.

\section{Basement of the Mid North Sea High}

The pre-Devonian basement in the region between the DSHFZ and the Trans-European Fault Zone is deeply buried except across the Mid North Sea High, where the inferred trace of the lapetus Suture (after Soper et al. 1992), and the Trans-European Fault Zone (after Berthelsen 1992) must meet (Fig. 1). Most of the deep basement provings described by Frost et al. (1981) appear to lie between the westward projections of the TEFZ and the Marginal Thrust Belt (Fig. 1). The boreholes P-1 (Denmark), 3/7-1 (Norway), B4-1, Q-1, Flensburg and Westerland (Germany) and 30/16-5 (UK) penetrated phyllitic schists yielding ${ }^{40} \mathrm{Ar}^{39}{ }^{30}$ ages in the range of 435-450 Ma, interpreted by Frost et al. (1981) as the age of prograde metamorphism in greenschist, and possible amphibolite facies, and 400-415 Ma (possible greenschist facies retrogression). The provenance of the metasedimentary protolith of these schists is unknown. Metamorphism of this intensity at about $440 \mathrm{Ma}$ is unknown from the microplate of Eastern Avalonia SW of the DSHFZ, although less intense late Ordovician deformation has been described from the Welsh Borders ('Shelveian event') by Toghill (1992) and northern England (Arthurton et al. 1988). Regional considerations suggest that the most likely cause of the highgrade metamorphism recognised in the basement of the Mid North Sea High was the collision of Baltica and Avalonia in late Ordovician time.

Clearly, the composition and affinities of the crust of the southern and central North Sea are matters of considerable interest to the EUROPROBE project. Further studies of the borehole samples from the Mid North Sea High described and dated by Frost et al. (1981) should be a priority of the project, as an adjunct to ongoing geophysical studies e.g. the MONA-LISA deep seismic profiling (BIRPS, 1993) so that this important crustal unit can be characterised. These studies should include: $\mathrm{Nd}, \mathrm{Pb}$ and $\mathrm{Sr}$ whole rock isotopes, and whole-rock geochemistry, to establish the affinities and crustal-residence history; U-Pb mineral ages to date igneous and metamorphic history, and confirm the ${ }^{40} \mathrm{Ar}-{ }^{39} \mathrm{Ar}$ ages; petrographic and structural studies to determine metamorphic grade and P-T paths for the North Sea basement.

\section{Timing of terrane amalgamation}

Palaeogeographic reconstructions of the early Palaeozoic evolution of southern Britain based upon palaeomagnetic evidence have described the northward drift of Avalonia from high southerly latitudes (about $60^{\circ} \mathrm{S}$ ) to about $30^{\circ} \mathrm{S}$ by early Silurian time (Torsvik \& Trench 1991, Scotese \& McKerrow 1991, Trench et al. 1992), when it was brought into juxtaposition with Baltica and Laurentia. Biogeographic data on faunal provinciality (Cocks \& Fortey 1982) and $\mathrm{Nd}$ isotopic data for sediment provenance suggest that the Avalonia Microplate was isolated from other continental masses during this oceanic drift. It is inferred that this rapid northward drift and collision with Baltica were achieved by the destruction of oceanic lithosphere (lapetus-Tornquist Ocean) along the northern edge of Avalonia. The palaeomagnetic data also indicate that the northward drift was accompanied by counter-clockwise rotation of the microplate, perhaps by as much as $55^{\circ}$ over the period $470-400 \mathrm{Ma}$, with most of this 
achieved by $450 \mathrm{Ma}$, according to Fig. 1 of Trench et al. (1992). This was probably accompanied by oblique closure, with dextral shear, of Tornquist's Sea (Trench et al. 1992). Pharaoh et al. (1993) highlighted the progressive change in age of calc-alkaline magmatism around the northern edge of the Avalonia Microplate, from Tremadoc-Arenig in Wales (Kokelaar et al. 1984), to Llandeilo-Caradoc in northern England (Cooper et al., 1993), Caradoc in eastern England (Noble et al. 1993) and Ashgill in Belgium (André et al. 1986). They suggested that this magmatic trend might be a function of the oblique closure of the Tornquist Sea and the counter-clockwise rotation of Avalonia with respect to a subduction zone (or zones) located to the north of Avalonia, a concept compatible with palaeomagnetic evidence for rotation (Trench et al. 1992). A recent analogue for such microplate rotation could be the Fiji microplate of the West Pacific. Subduction-magmatism in southern Britain ceased in Ashgill time, about the same time that the isolation of Avalonia measured in terms of faunal provinciality (Cocks \& Fortey 1982) and crustal provenance (Thorogood 1990) ended.

Some authors (e.g. Pickering et al. 1988) have proposed a 'soft' collision between Avalonia and Baltica at this time. However, the presence of high grade metamorphic rocks on the mid North Sea High yielding late Ordovician Ar-Ar ages interpreted as the date of prograde metamorphism (Frost et al. 1981), and evidence for late Ordovician ('Shelveian') deformation in the Welsh Borders and northern England suggest that the collision of Avalonia and Baltica in late Ordovician time was anything but soft. Our preferred model involves overthrusting of the basement of the Anglo-Dutch Basin by Avalonia along thje Dowsing-South Hewett Suture, the Caledonian antecedent of the DSHFZ, and thrusting within the concealed Caledonides of eastern England. The nature of the tectonic interraction between Avalonia and Baltica along the TEFZ is presently unclear, but is a primary objective of the the recently acquired MONALISA deep seismic profiles. More detailed studies of the crust of the southern and central North Sea are required to determine its history and affinity. Away from the collision zone, in the heart of Avalonia, deformation was more heterogeneous in nature, restricted largely to the reactivation of ancient lineaments such as the Welsh Borderland Fault System.

By Llandovery time, the Anglian Basin (Woodcock \& Pharaoh 1993) had become established and was receiving deep-water muddy detritus from an unknown source, perhaps the basement of the North Sea or Baltica. Subduction of lapetus Ocean continued to the NW, beneath Laurentia, during Llandovery and Wenlock time (Leggett et al. 1979). By late Wenlock time, turbiditic sandstones of $\mathrm{N}$ England are petrographically, chemically and isotopically indistinguishable from contemporary strata in the Southern Uplands (McCaffrey, 1991). Sediment from Laurentia was by now being fed across to Avalonia (Kemp 1987) and the lapetus Collision Zone was being buried beneath a developing foreland basin (Kneller 1991). The prograding thrust front of this basin migrated southwards through late Silurian time (Kneller et al. 1993). The Acadian deformation phase, in the Emsian, may have resulted from compression of Avalonia from the south as a result of an early phase of closure of the Rheic ocean basin. As a result of this jostling, the SW-NE trending lapetus collision zone of western Britain was reactivated, generating sinistral transpression along crustal lineaments and the clockwise transection of cleavage recognised in the early Palaeozoic slate belts in Wales, the Lake District and Southern Uplands (Soper et al. 1987). On the eastern side of Britain, in the southern North Sea, the NW-SE trending DSHFZ and TEFZ were probably reactivated as dextral transpressional structures, and Silurian-early Devonian strata in the Anglian Basin were cleaved for the first time. 


\section{Acknowledgements}

We gratefully acknowledge funding from the European Science Foundation which enabled our participation at the Liblice Meeting. TCP publishes with the permission of Director, British Geological Survey (NERC).

\section{References}

ALLSOP, J.M. 1987. Patterns of late Caledonian intrusive activity in eastern and northern England from geophysics, radiometric dating and basement geology. Proceedings of the Yorkshire Geological Society 46, 335-353.

ANDRÉ, L. 1991. The concealed crystalline basement in Belgium and the "Brabantia" microplate concept: constraints from the Caledonian magmatic and sedimentary rocks. Annales de la Société Géologique de Belgique 114, 117-140.

ANDRÉ, L., HERTOGEN, J. \& DEUTSCH, S. 1986. OrdovicianSilurian magmatic provinces in Belgium and the Caledonian orogeny in middle Europe. Geology 14, 879-882.

ARTHURTON, R.S., JOHNSON, E.W. \& MUNDY, D.J.C. 1988. Geology of the country around Settle. Memoir of the Geological Survey of Great Britain.

BERTHELSEN, A. 1983. The early (800-300 Ma) crustal evolution of the off-shield regions of Europe. p125-142 in Proceedings of the First Workshop on the European Geotraverse (EGT) project - the northern segment. European Science Foundation, Strasbourg.

BERTHELSEN, A. 1992. Mobile Europe. Chapter 2 In: BLUNDELL, D., FREEMAN, R. \& MUELLER, S. A Continent Revealed: The European Geotraverse. Cambridge University Press p11-32.

BEVINS, R.E., KOKELAAR, B.P. \& DUNKLEY, P.N. 1984. Petrology and geochemistry of early to mid-Ordovician igneous rocks in Wales: a volcanic arc to marginal basin transition. Proceedings of the Geologists' Association 95, 337-347.

BLUNDELL, D. 1993. Deep structure of the Anglo-Brabant Massif revealed by seismic profiling. Geological Magazine 130, 563-567.

BLUNDELL, D.J., HOBBS, R.W., KLEMPERER, S.L., SCOTT-ROBINSON, R., LONG, R.E., WEST, T.E. \& DUIN, E. 1991. Crustal structure of the central and southern North Sea from BIRPS deep seismic reflection profiling. Journal of the Geological Society, London 148, 445-458.

BULLARD, E.C. et al. 1940. Seismic Investigations on the Palaeozoic floor of East England. Philosophical Transactions of the Royal Society, London A239, 29pp.

BUSBY, J.P., KIMBELL, G.S. \& PHARAOH, T.C. 1993. Integrated geophysical/geological modelling of the Caledonian and Precambrian basement of southern Britain. Geological Magazine 130, 593-604. 
CAMERON, T.D.J., CROSBY, A., BALSON, P.S., JEFFERY, D.H., LOTT, G.K., BULAT, J. and HARRISON, D.J. 1992. United Kingdom offshore regional report: the geology of the southern North Sea. (London: HMSO for the British Geological Survey.)

CARNEY, J., GLOVER, B.J. \& PHARAOH, T.C. 1992. Pre-conference field excursion guide: Midlands. British Geological Survey Technical Report WA/92/72, 28pp.

CHADWICK, R.A., KENOLTY, N. \& WHITTAKER, A. 1983. Crustal structure beneath southern England from deep seismic reflection profiles. Journal of the Geological Society of London 140, 893-911.

COCKS, L.R.M \& FORTEY, R.A. 1982. Faunal evidence for oceanic separations in the Palaeozoic of Britain. Journal of the Geological Society of London 139, 465-478.

COPE, J.C.W., INGHAM, J.K. \& RAWSON, P.F. 1992. Atlas of Palaeogeography and Lithofacies. Geological Society of London.

CORNWELL, J.D. \& WALKER, A.S.D. 1989. Chapter 4. Regional Geophysics. In Metallogenic models and exploration criteria for buried carbonate-hosted ore deposits-a multidisciplinary study in eastern England (eds J.A.PLANT \& D.G.JONES), pp.25-52. London: The Institution of Mining and Metallurgy and British Geological Survey, 161pp.

DE VOS, W., VERNIERS, J., HERBOSCH, A. \& VANGUESTAINE, M. 1993. A new geological map of the Brabant Massif, Belgium. Geological Magazine 130, 605-611.

DEWEY, J.F. 1969. Evolution of the Appalachian-Caledonian Orogen. Nature 222, 124-8.

DONATO, J.A., MARTINDALE, W. and TULLY, M.C. 1983. Buried granites within the Mid North Sea High. Journal of the Geological Society of London 140, 825-837.

and MEGSON, J.B. 1990. A buried granite batholith beneath the East Midlands Shelf of the Southern North Sea Basin. Journal of the Geological Society of London 147, 133-140.

FREEMAN, B., KLEMPERER, S.L. and HOBBS, R.W. 1988. The deep structure of northern England and the lapetus Suture zone from BIRPS deep seismic reflection profiles. Journal of the Geological Society of London 145, 727-740.

FROST, R.T.C., FITCH, F.J. and MILLER, J.A. 1981. The Age and Nature of the Crystalline Basement of the North Sea Basin. 43-57 in Petroleum Geology of the Continental Shelf of North-West Europe. (London:Institute of Petroleum).

GLENNIE, K.W. 1986. The structural framework and the pre-Permian history of the North Sea area. 25-62 in Introduction to the petroleum geology of the North Sea (2nd edition). GLENNIE, K.W. (editor). (Oxford: Blackwell Scientific Publications).

_ and BOEGNER, P.L.E. 1981. Sole Pit Inversion tectonics. 110-120 in Petroleum geology of 
the continental shelf of North-West Europe. ILLING, L.V. and HOBSON, G.D. (editors). (London: Heyden and Sons.)

HARLAND, W.B., ARMSTRONG, R.L., COX, A.V., CRAIG, L.E., SMITH, A.G. \& SMITH, D.G. 1989. A Geologic Time Scale 1989. Cambridge University Press.

KATZUNG, G., GIESE, U., WALTER, R. \& VON WINTERFELD, C. 1993. The Rugen Caledonides, northeast Germany. Geological Magazine 130, 725-730.

KEMP, A.E.S. 1987. Evolution of Silurian depositional systems in the Southern Uplands of Scotland. In: LEGGETT, J.K. \& ZUFFA, G.G. Marine clastic sedimentology: concepts and case studies. pp124-155. Graham \& Trotman, London.

KLEMPERER, S.L. \& HOBBS, R. 1992. The BIRPS Atlas. Deep seismic reflection profiles around the British Isles. Cambridge University Press, Cambridge.

KLEMPERER, S.L., HAUGE, T.A., HAUSER, E.C., OLIVER, J.E. and POTTER, C.J. 1986. The Moho in the northern Basin and Range province, Nevada, along the COCORP $40^{\circ} \mathrm{N}$ seismic reflection transect. Geological Society of America Bulletin 97, 603-618.

and HOBBS, R. 1992. The BIRPS Atlas. Deep seismic reflection profiles around the British Isles. (Cambridge: Cambridge University Press)

KNELLER, B.C. 1991. A foreland basin on the southern margin of lapetus. Journal of the Geological Society of London 148, 207-210.

KNELLER, B.C., KING, L.M. \& BELL, A.M. Foreland basin development and tectonics on the northwest margin of eastern Avalonia. Geological Magazine 130, 691-697.

KOKELAAR, B.P., HOWELLS, M.F., BEVINS, R.E., ROACH, R.A. \& DUNKLEY, P.N. 1984. The Ordovician marginal basin of Wales. In Volcanic and associated sedimentary and tectonic processes in modern and ancient marginal basins (eds B.P.KOKELAAR \& M.F. HOWELLS), pp245-270. Special Publication, Geological Society of London no 16. Oxford: Blackwell Scientific Publications, 322pp.

LE BAS, M.J. 1972. Caledonian igneous rocks beneath central and eastern England. Proceedings of the Yorkshire Geological Society 39, 71-86.

LE BAS, M.J. 1982. Geological evidence from Leicestershire on the crust of southern Britain. Transactions of the Leicester Literary and Philosophical Society 76, 54-67.

LEE, M.K., PHARAOH, T.C. and GREEN, C.A. 1991. Structural trends in the concealed Caledonide basement of eastern England from images of regional potential field data. In: Proceedings of the International Meeting on the Caledonides of the Midlands and the Brabant Massif. ANDRE, L., HERBOSCH, A., VANGUESTAINE, M. and VERNIERS, J. (editors). Annales de la Société Géologique de Belgique 114, 45-62. 
LEE, M.K., PHARAOH, T.C. and SOPER, N.J. 1990. Structural trends in central Britain from images of gravity and aeromagnetic fields. Journal of the Geological Society of London 147, 241-258.

LEE, M.K., PHARAOH, T.C., WILLIAMSON, J.P., GREEN, C.A. and DE VOS, W. 1993. Evidence on the deep structure of the Anglo-Brabant Massif from gravity and magnetic data. Geological Magazine 130, 575-582.

LEEDER, M.R. \& HARDMAN, M. 1990. Carboniferous of the Southern North Sea Basin and controls on hydrocarbon prospectivity. 87-105 in Tectonic events responsible for Britain's oil and gas reserves. HARDMAN, R.F.P. and BROOKS, J. (editors). Special Publication of the Geological Society of London, 55.

LEGGETT, J.K., McKERROW, W.S. \& EALES, M.H. 1979. The Southern Uplands of Scotland, a lower Palaeozoic accretionary prism.

Journal of the Geological Society, London 136, 755-770.

LYNAS, B.D.T. 1988. Evidence for dextral oblique-slip faulting in the Shelve Ordovician inlier, Welsh Borderland: implications for the south British Caledonides. Geological Journal 23, 3957.

McCAFFREY, W.D., BARON, H., MOLYNEUX, S.G. \& KNELLER, B.C. 1992. Recycled achritarchs provenance indicators: implications for Caledonian terrane reconstruction. Geological Magazine 129, .

MERRIMAN, R.J., PHARAOH, T.C., WOODCOCK, N.H. and DALY, P. 1993. The metamorphic history of the concealed Caledonides of eastern England and their foreland. Geological Magazine 130, 613-620.

MOLYNEUX, S.G. 1991. The contribution of palaeontological data to an understanding of the Early Palaeozoic framework of eastern England. In: Proceedings of the International Meeting on the Caledonides of the Midlands and the Brabant Massif. ANDRE, L., HERBOSCH, A., VANGUESTAINE, M. and VERNIERS, J. (editors). Annales de la Société Géologique de Belgique 114, 93-106.

NOBLE, S.R., TUCKER, R.D. \& PHARAOH, T.C. 1993.

Lower Palaeozoic and Precambrian igneous rocks from eastern England, and their bearing on late Ordovician closure of the Tornquist Sea: constraints from U-Pb and Nd isotopes., Geological Magazine 130, 738-747.

OLIVER, G.J.H., CORFU, F. \& KROGH, T.E. 1993. U-Pb ages from SW Poland: evidence for a Caledonian suture zone between Baltica and Gondwana. Journal of the Geological Society, London 150, 355-370.

PHARAOH, T.C. 1992. Chapter 2 Tectonic Overview In: Horscroft, T.R., Sutton, E.R., Davidson, K., Williamson, P., Rollin, K.E., Lee, M.K., Pharaoh, T.C. and Gibberd, A.J. Intera/BGS SNS Carboniferous Project (Confidential), 20p. 
PHARAOH, T.C., ALLSOP, J.M., RUNDLE, C.C., HOLLIDAY, D.W., MERRIMAN, R.J. \& EVANS, C.J. 1990. A pre-Carboniferous microgranite in the Claxby No. 1 Borehole, Lincolnshire, and its regional implications. Technical Report WA/90/80C, Onshore Geology Series, British Geological Survey, 27pp.

PHARAOH, T.C., BREWER, T.S. and WEBB, P.C. 1993. Subduction-related magmatism of late Ordovician age in eastern England. Geological Magazine 130, 647-656.

PHARAOH, T.C., MERRIMAN, R.J., EVANS, J.A., BREWER, T.S., WEBB, P.C. \& SMITH, N.J.P. 1991. Early Palaeozoic arc-related volcanism in the concealed Caledonides of southern Britain. Annales de la Société Géologique de Belgique 114, 63-91.

PHARAOH, T.C., MERRIMAN, R.J., WEBB, P.C. \& BECKINSALE, R.D. 1987a. The concealed Caledonides of eastern England: preliminary results of a multidisciplinary study. Proceedings of the Yorkshire Geological Society 46, 355-369.

PHARAOH, T.C., MOLYNEUX, S.G., MERRIMAN, R.J., LEE, M.K. and VERNIERS, J. 1993. The Caledonides of the Anglo-Brabant Massif reviewed. Geological Magazine 130, 561-562.

PHARAOH, T.C., WEBB, P.C., THORPE, R.S. \& BECKINSALE, R.D. 1987b. Geochemical evidence for the tectonic setting of late Proterozoic volcanic suites in central England. In Geochemistry and Mineralization of Proterozoic volcanic suites (eds T.C.PHARAOH, R.D.BECKINSALE \& D.RICKARD), pp.541-552. Special Publication, Geological Society of London no 33. Oxford: Blackwells Scientific Publications, 575pp.

PICKERING, K.T. 1989. The destruction of lapetus and Tornquist's Oceans. Geology Today 5, 160-166.

PICKERING, K.T., BASSETT, M.G. \& SIVETER, D.J. 1988. Late Ordovician-early Silurian destruction of the lapetus Ocean: Newfoundland, British Isles and Scandinavia - a discussion. Transactions of the Royal Society of Edinburgh: Earth Sciences 79, 361-382.

PIDGEON, R.T. \& AFTALION, M. 1978. Cogenetic and inherited zircon U-Pb systems in Palaeozoic granites from Scotland and England. In Crustal evolution in northwest Britain and adjacent regions (eds D.R.BOWES \& B.E.LEAKE), pp 183-220. Geological Journal Special Issue 10. Liverpool, Seal House Press.

RESTON, T.J. \& BLUNDELL, D.J. 1987. Possible mid-crustal shears at the edge of the London Platform. Geophysical Journal of the Royal Astronomical Society 89, 251-258.

RODGERS, G., DEMPSTER, T.J., BLUCK, B.J. \& TANNER, P.W.G. 1989.

A high precision $\mathrm{U}-\mathrm{Pb}$ age for the Ben Vuirich granite: implications for the evolution of the Scottish Dalradian Supergroup. Journal of the Geological Society, London 146, 789-798.

SCOTESE, C.R. \& McKERROW, W.S. 1991. Ordovician plate tectonic reconstructions. In: BARNES, C.R. \& WILLIAMS, S.H. (Eds) Advances in Ordovician Geology Geological Survey of Canada Paper 90-9, 271-282. 
SERVAIS, T., VANGUESTAINE, M. \& HERBOSCH, A. 1993. Review of the stratigraphy of the Ordovician in the Brabant Massif, Belgium. Geological Magazine 130, 699-710.

SMITH, N.J.P. (Compiler) 1985. Pre-Permian geology of the United Kingdom (South). British Geological Survey.

SMITH, N.J.P. \& RUSHTON, A.W.A., 1993. Cambrian and Ordovician stratigraphy related to structure and seismic profiles in the western part of the English Midlands. Geological Magazine 130, 665-671.

SOPER, N.J., ENGLAND, R.W., SNYDER, D.B. \& RYAN, P.D. 1992. The lapetus suture zone in England, Scotland and eastern Ireland: a reconciliation of geological and deep seismic data. Journal of the Geological Society, London 149, 697-700.

SOPER, N.J., WEBB, B.C. \& WOODCOCK, N.J. 1987. Late Caledonian (Acadian) transpression in North West England: timings, geometry and geotectonic significance. Proceedings of the Yorkshire Geological Society 46, 175-192.

STILLMAN, C.J. 1988. Ordovician to Silurian volcanism in the Appalachian-Caledonian orogen. In The Caledonian-Appalachian Orogen (eds A.L.HARRIS \& D.J.FETTES), pp275-290. Special Publication, Geological Society of London no. 38. Oxford: Blackwells Scientific Publications, 643pp.

THOROGOOD, E.J. 1990. Provenance of the Pre-Devonian sediments of England and Wales. Journal of the Geological Society, London 147, 591-4.

THORPE, R.S., BECKINSALE, R.D., PATCHETT, P.J., PIPER, J.D.A., DAVIES, G.R. and EVANS, J.A. 1984. Crustal growth and the late Precambrian-early Palaeozoic plate tectonic evolution of England and Wales. Journal of the Geological Society of London 141, 521-536.

THORPE, R.S., GASKARTH, J.W. \& HENNEY, P. 1993. Tectonic setting of Caledonian minor intrusions of the English Midlands. Geological Magazine 130, 657-663.

TOGHILL, P. 1992. The Shelveian event, a late Ordovician tectonic episode in Southern Britain (Eastern Avalonia). Proceedings of the Geologists' Association 103, 31-35.

TORSVIK, T.H. \& TRENCH, A. 1991. The Ordovician history of the lapetus Ocean in Britain: new palaeomagnetic constraints. Journal of the Geological Society, London 148, 423-425.

TUCKER, R.D. \& PHARAOH, T.C. 1991. U-Pb zircon ages for Late Precambrian igneous rocks in southern Britain. Journal of the Geological Society, London 148, 435-443.

TURNER, J.S. 1949. The deeper structure of central and northern England. Proceedings of the Yorkshire Geological Society 27, 280-297.

VERNIERS, J. \& VAN GROOTEL, G. 1991. Review of the Silurian in the Brabant Massif, Belgium. 
In: Proceedings of the International Meeting on the Caledonides of the Midlands and the Brabant Massif. ANDRE, L., HERBOSCH, A., VANGUESTAINE, M. and VERNIERS, J. (editors). Annales de la Société Géologique de Belgique 114, 163-194.

WILLS, L.J. 1978. A Palaeogeological map of the Lower Palaeozoic Floor, below the cover of Upper Devonian, Carboniferous and later formations. Geological Society of London, Memoir 8, 36pp.

WOODCOCK, N.H. 1991. The Welsh, Anglian and Belgian Caledonides compared. In: Proceedings of the International Meeting on the Caledonides of the Midlands and the Brabant Massif. ANDRE, L., HERBOSCH, A., VANGUESTAINE, M. and VERNIERS, J. (editors). Annales de la Société Géologique de Belgique 114, 5-18.

WOODCOCK, N.H. \& FISCHER, M. 1986. Strike-slip duplexes.

Journal of Structural Geology 8, 725-735.

WOODCOCK, N.H. \& GIBBONS, W. 1988. Is the Welsh Borderland Fault System a terrane boundary?. Journal of the Geological Society, London 145, 915-933.

WOODCOCK, N.H. \& PHARAOH, T.C. 1993. Silurian facies beneath East Anglia. Geological Magazine 130, 681-690.

ZIEGLER, P.A. 1982. Geological atlas of Western and Central Europe. (Amsterdam: Shell International Petroleum Maatschappij BV.)

\section{Figure captions}

Fig. 1. Caledonian basement of the North Sea region.

Main structural elements after Lee et al. (1990), Berthelsen (1992), Soper et al. (1992), De Vos (1993) and Katzung (1993).

Key to structural elements:

BF Bala Fault, CDF Caledonian Deformation Front, DSHFZ Dowsing-South Hewett Fault Zone, FB Faille Bordiere, HBF Highland Boundary Fault, IS lapetus Suture, MSFS Menai Straits Fault System, PM Pendle Monocline, SUF Southern Uplands Fault, TEFZ Trans-European Fault Zone, VF Variscan Front, WBFS Welsh Borderland Fault System, WGB Windermere Group Basin

Key to igneous complexes:

LDB Lake District Batholith, MW Market Weighton Granite (inferred), WB Wash Batholith, WdB Weardale Batholith, WyB Wensleydale Batholith

Key to onshore boreholes: 
Cl Claxby, F Flensburg, Gl Glamsbjerg, Gr Grinsted, NC North Creake, R Raydale, W Westerland, We Weeley

Fig. 2. MOBIL-7 profile and model, reproduced with permission from Lee et al. (1993). 